\title{
(GIGA)bYte
}

\section{Annotation of yellow genes in Diaphorina citri, the vector for Huanglongbing disease}

\author{
Crissy Massimino ${ }^{1}$, Chad Vosburg ${ }^{1}$, Teresa Shippy ${ }^{2}$, Prashant S. Hosmani ${ }^{3}$, \\ Mirella Flores-Gonzalez ${ }^{3}$, Lukas A. Mueller ${ }^{3}$, Wayne B. Hunter ${ }^{4}$, \\ Joshua B. Benoit ${ }^{5}$, Susan J. Brown ${ }^{2}$, Tom D’Elia ${ }^{1}$ and Surya Saha ${ }^{3,6, *}$ \\ 1 Indian River State College, Fort Pierce, FL 34981, USA \\ Division of Biology, Kansas State University, Manhattan, KS 66506, USA \\ Boyce Thompson Institute, Ithaca, NY 14853, USA \\ 4 USDA-ARS, US Horticultural Research Laboratory, Fort Pierce, FL 34945, USA \\ 5 Department of Biological Sciences, University of Cincinnati, Cincinnati, OH 45221, USA \\ 6 Animal and Comparative Biomedical Sciences, University of Arizona, Tucson, AZ 85721, USA
}

\section{ABSTRACT}

Huanglongbing (HLB), also known as citrus greening disease, is caused by the bacterium Candidatus Liberibacter asiaticus (CLas). It is a serious threat to global citrus production. This bacterium is transmitted by the Asian citrus psyllid, Diaphorina citri (Hemiptera). There are no effective in planta treatments for CLas. Therefore, one strategy is to manage the psyllid population. Manual annotation of the $D$. citri genome can identify and characterize gene families that could be novel targets for psyllid control. The yellow gene family is an excellent target because yellow genes, which have roles in melanization, are linked to development and immunity. Combined analysis of the genome with RNA-seq datasets, sequence homology, and phylogenetic trees were used to identify and annotate nine yellow genes in the $D$. citri genome. Manual curation of genes in $D$. citri provided in-depth analysis of the yellow family among hemipteran insects and provides new targets for molecular control of this psyllid pest. Manual annotation was done as part of a collaborative Citrus Greening community annotation project.

Submitted: 21 December 2020

Accepted: $\quad 18$ May 2021

Published: $\quad 24$ May 2021

* Corresponding author. E-mail: suryasaha@cornell.edu

Published by GigaScience Press.

Preprint submitted at https: //doi.org/10.1101/2020.12.22.422960

Included in the series: Asian citrus psyllid community annotation (https://doi.org/10.46471/GIGABYTE_ SERIES_0001)

This is an Open Access article distributed under the terms of the Creative Commons Attribution License (http://creativecommons.org/ licenses/by/4.0/), which permits unrestricted reuse, distribution, and reproduction in any medium, provided the original work is properly cited.

Gigabyte, 2021, 1-15
Subjects Genetics and Genomics, Animal Genetics, Bioinformatics

\section{DATA DESCRIPTION}

\section{Introduction}

Huanglongbing (HLB), also known as citrus greening disease, is the most serious threat to citrus sustainability [1-4]. HLB is caused by the bacterium Candidatus Liberibacter asiaticus (CLas) [5]. The Asian citrus psyllid, Diaphorina citri (NCBI:txid121845), is the vector for CLas (Hemiptera: Liviidae) [6]. There is no effective treatment for the pathogen, and pesticide application is the only mechanism to reduce psyllid populations [4]. However, current control strategies are not effective, so the development of novel mechanisms to reduce the psyllid vector population is necessary. Manual annotation of the $D$. citri genome to identify and characterize genes could identify targets for psyllid control treatments [7-9].

Here, we identified and characterized genes in the yellow gene family. The yellow proteins (dopachrome conversion enzymes, DCE) are involved in melanin biosynthesis [10]. Melanization is a critical function in insects [11]. Melanization can be triggered locally as an 


\begin{tabular}{|c|c|c|c|c|c|c|}
\hline Gene & Identifier & MCOT & $\begin{array}{c}\text { de novo } \\
\text { transcriptome }\end{array}$ & Iso-seq & RNA-seq & Ortholog \\
\hline yellow $(y)$ & Dcitr06g10150.1.1 & MCOT10626.0.MT & $\mathrm{X}$ & $\mathrm{X}$ & $\mathrm{X}$ & \\
\hline yellow $2(y 2)$ & Dcitr03g06860.1.1 & & $\mathrm{X}$ & $\mathrm{X}$ & $\mathrm{X}$ & \\
\hline yellow $3(d)$ & Dcitr07g07190.1.1 & МСОТ21608.0.СТ & $\mathrm{X}$ & & $\mathrm{X}$ & \\
\hline yellow $4(h)$ & Dcitr07g07210.1.1 & МСОТ05770.2.СC & $\mathrm{X}$ & $\mathrm{X}$ & $\mathrm{X}$ & $\mathrm{X}$ \\
\hline yellow $5(d)$ & Dcitr11g08710.1.1 & МСОТ00471.2.CO & $\mathrm{X}$ & & $\mathrm{X}$ & $\mathrm{X}$ \\
\hline yellow $6(\mathrm{~g})$ & Dcitr02g17890.1.1 & MCOT15143.1.CC & $\mathrm{X}$ & $\mathrm{X}$ & $\mathrm{X}$ & $\mathrm{X}$ \\
\hline yellow $7(g)$ & Dcitr11g06750.1.1 & MCOT19435.0.CO & $\mathrm{X}$ & $\mathrm{X}$ & $\mathrm{X}$ & $\mathrm{X}$ \\
\hline yellow $8(c)$ & Dcitr01g01210.1.1 & & $\mathrm{X}$ & $\mathrm{X}$ & $\mathrm{X}$ & $\mathrm{X}$ \\
\hline yellow 9 & Dcitr01g05760.1.1 & MCOT08915.0.MM & $\mathrm{X}$ & & $\mathrm{X}$ & \\
\hline
\end{tabular}

immune effector response, in which melanin is synthesized and cross-linked with other molecules in injured areas, resulting in the death of invading pathogens and hardening of the wound clot [12]. Melanization is also essential for cuticle sclerotization or tanning, which leads to hardening of the insect exoskeleton [13], and the prevention of moisture loss [10]. To develop gene-targeting or gene-suppressing treatments for yellow proteins, accurate gene sequences need to be established, annotated, and basic expressional details provided. Here we describe the yellow genes of $D$. citri using a combination of genome annotation and expressional differences [14] based on previously conducted RNA-seq studies.

\section{Context}

The yellow genes are of ancient lineage, as evidenced by the presence of yellow-like genes in several bacterial species. However, there is no evidence that these genes exist in the complete genome sequences of the worm Caenorhabditis elegans or the yeast Saccharomyces cerevisiae. This suggests that they may have been lost from many lineages and may now be largely restricted to arthropods [15]. While functional assignments have not yet been made for every member of this family, research suggests that a role in melanization may be conserved for several yellow family members [11]. Duplications, as well as losses, are apparent in the yellow gene family, and phylogenetic analysis shows that yellow family expansion is associated with insect diversification [11]. Previous studies have shown that the yellow- $y,-c$, $-d,-e,-f,-g$, and $-h$ genes were present prior to divergence of the hemimetabolous and holometabolous insects; however, some of these ancestral yellow genes are lost in specific insect lineages [11]. The most notable case of yellow lineage duplication is the entire major royal jelly protein (mrjp) family, which forms a distinct cluster within the yellow family phylogeny and seems to be restricted to certain species of bees (Figure 1) [15]. Here we describe the yellow genes of the Asian citrus psyllid, Diaphorina citri. Because of the multiplicity of yellow genes discovered in D. citri and the inconsistency of ortholog names, phylogenetic analysis was performed to properly classify these genes. This was followed by examining expression differences based on previously available RNA-seq datasets. Based on these results, we discuss possible functions of the yellow genes identified in $D$. citri.

\section{METHODS}

The $D$. citri genome was annotated as part of a community-driven manual curation project [9] with an undergraduate focus [16]. Protein sequences of the yellow family were 


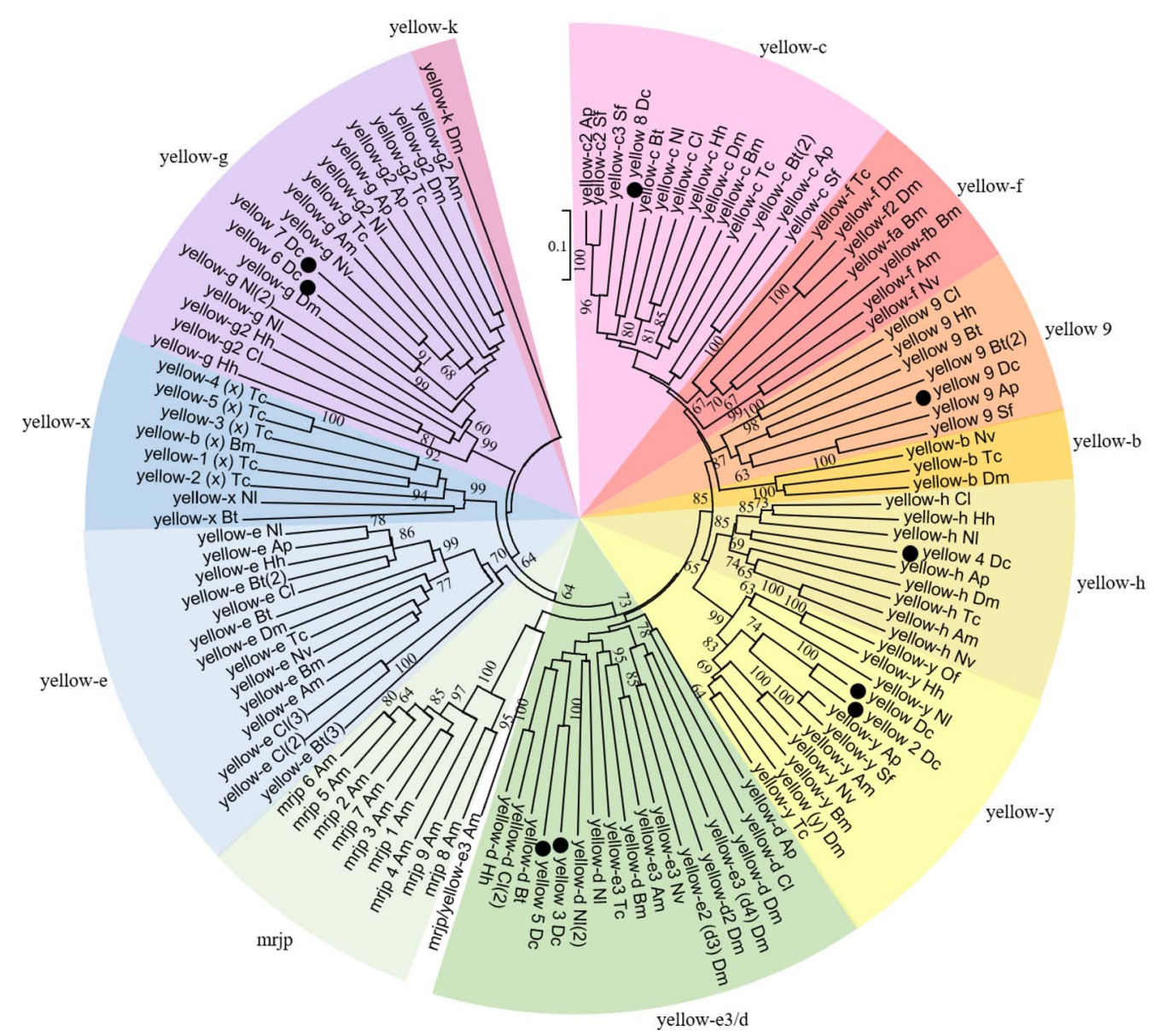

Figure 1. The yellow gene family. A neighbor-joining phylogenetic tree was generated from annotated $D$. citri (Dc) yellow protein sequences and the protein sequence of all predicted yellow genes from the insects Acyrthosiphon pisum (Ap), Apis mellifera (Am), Tribolium castaneum ( $(T c)$, Drosophila melanogaster (Dm), Bombyx mori (Bm), Sipha flava (Sf), Bemisia tabaci (Bt), Nilaparvata lugens ( $N l)$, Cimex lectularius $(\mathrm{Cl})$, Halyomorpha halys (Hh). Also included are sequences from Nasonia vitripennis $(\mathrm{Nv})$ and Oncopeltus fasciatus $(\mathrm{Of})$. Bootstrap analysis was performed with 1000 replicates. Values greater than 60 are shown at nodes. $D$. citri sequences are identified with a dot. Color coding indicates specific yellow clades. NCBI accession numbers are shown in Tables 2 and 3.

collected from the National Center for Biotechnology Information (NCBI) protein database [17] and were used for a BLAST search of the D. citri MCOT (Maker (RRID:SCR_005309), Cufflinks (RRID:SCR_014597), Oases (RRID:SCR_011896), and Trinity (RRID:SCR_013048)) protein database [14]. MCOT protein sequences were used to search the D. citri genomes (version 2.0 and 3.0) [18]. Regions of high sequence identity were manually annotated in Apollo version 2.1.0 (RRID:SCR_001936), using de novo transcriptome and MCOT gene predictions, RNA-seq, Iso-seq, and ortholog data as evidence to determine and validate proper gene structure (Table 1). The gene models were compared with those from other hemipterans for accuracy and completeness. A neighbor-joining phylogenetic tree of D. citri yellow protein sequences, along with various related orthologs, was created in MEGA version 7 (RRID:SCR_000667) using the MUSCLE (RRID:SCR_011812) multiple sequence alignment with p-distance for determining branch length and 1000 bootstrap replicates [19]. A more detailed description of the annotation workflow is available (Figure 2) [20]. 


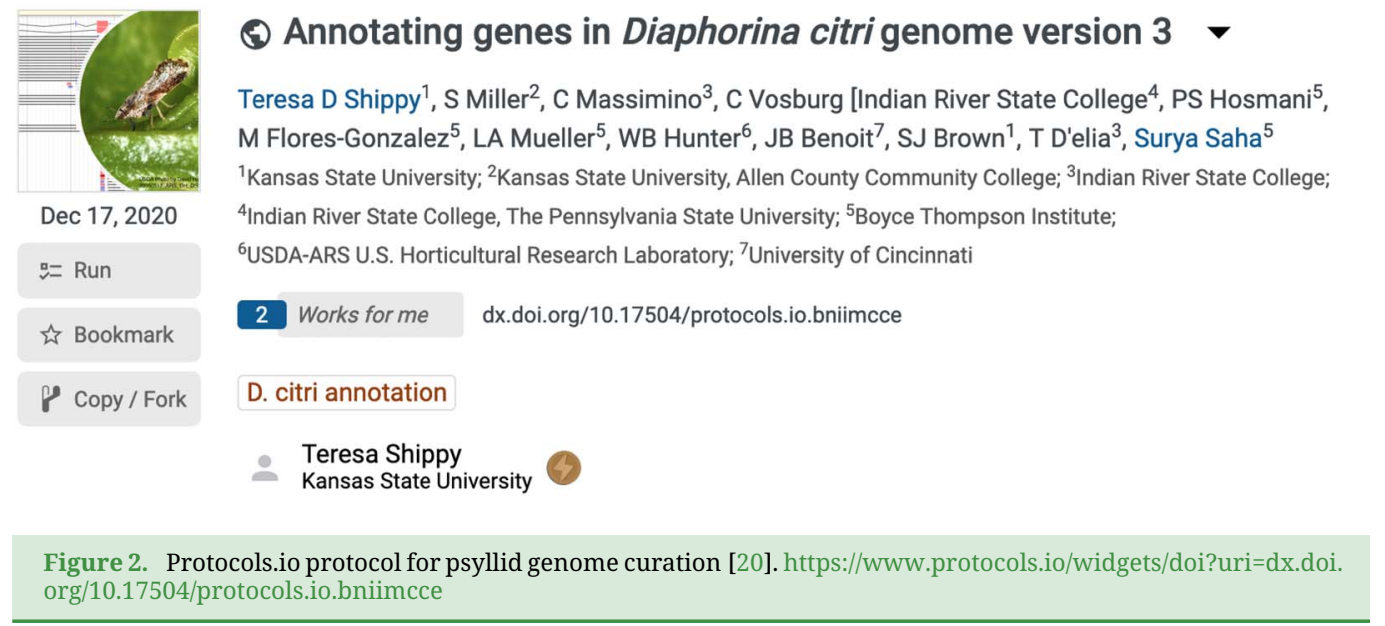

Accession numbers for the sequences used in this analysis can be found in Tables 1, 2, and 3. Comparative expression levels of yellow proteins throughout different life stages (egg, nymph, and adult) in Candidatus Liberibacter asiaticus (Clas) exposed versus healthy $D$. citri insects was determined using RNA-seq data and the Citrus Greening Expression Network [14]. Gene expression levels were obtained from the Citrus Greening Expression Network [14] and visualized using Excel (RRID:SCR_016137) and the pheatmap package in R (RRID:SCR_016418) [21, 22]. Expression values for all samples discussed in this manuscript and visualized in Figures 3-7 are reported in Table 4.

\section{Data validation and quality control}

Manual gene annotation of the $D$. citri genome revealed the presence of nine yellow genes, each containing the major royal jelly protein (mrjp) domain conserved in this gene family. All nine of the genes were confirmed by at least four types of evidence, including RNA-seq and ortholog presence (Table 1). Phylogenetic analysis was conducted to determine the orthology of these yellow genes; the results coincide well with previous studies (Figure 1) [11, 27]. Based on this analysis, the yellow genes in D. citri comprise two yellow-y genes, two yellow-d genes, two yellow-g genes, one yellow- $h$, and one yellow-c, as well as one yellow gene (yellow 9) that seems to be a duplication unique to hemipterans, but is closely related to known yellow- $f$ orthologs (Figure 1, Table 5).

Based on transcript and ortholog evidence, there are nine yellow genes in D. citri (Table 1). Each gene has been assigned an OGS3 identifier. Evidence from a de novo Oases or Trinity model from an independent transcriptome known as MCOT [9] was used to validate or improve our models. Illumina (RNA-Seq) reads were used to help create or validate our model. A de novo transcriptome was built from long RNA-Seq reads generated with Pacific Biosciences technology (Iso-Seq) and was used to help validate the exon structure of the models. These full-length transcripts allowed us to disambiguate noisy signals from short read RNA-seq data. Orthologous sequences from related insects and information about conserved motifs or domains were used to determine the final annotation. We used proteins from Drosophila melanogaster (Dm) [28], Tribolium castaneum (Tc) [29, 30], Bombyx mori (Bm) [31], Apis mellifera (Am) [32], Nasonia vitripennis (Nv) [33], Acyrthosiphon pisum (Ap) [34], Nilaparvata lugens ( $N l)$ [35, 36], Sipha flava (Sf) [37], Bemisia tabaci (Bt) [38], Halyomorpha halys (Hh) [39], Cimex lectularius (Cl) [40], and Oncopeltus fasciatus (Of) [41]. 


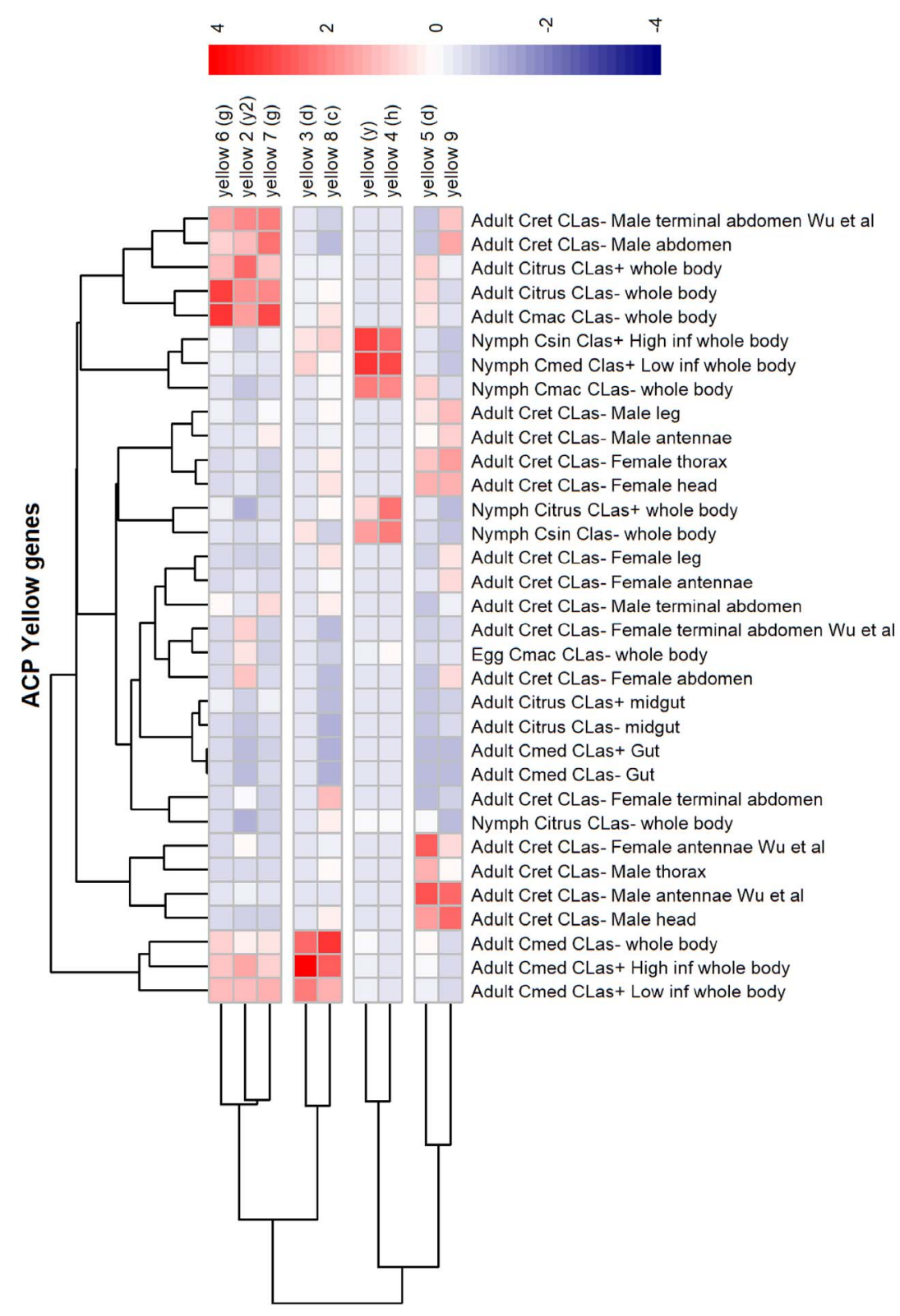

Figure 3. Comparative expression levels of the $D$. citri yellow-y proteins in infected vs. uninfected $D$. citri insects grown on various citrus varieties. Expression data were obtained using the Citrus Greening Expression Network [14]. RNA-seq data for psyllids were obtained from NCBI BioProject's PRJNA609978 and PRJNA448935 in addition to published data sets [8,23-26]. Citrus hosts are abbreviated as Csin ( $C$. sinensis), Cmed (C. medica), Cret (C. reticulata) and Cmac (C. macrophylla).

Table 5 lists yellow gene family ortholog numbers in A. pisum, A. mellifera, T. castaneum, D. melanogaster, B. mori, S. flava, B. tabaci, N. lugens, C. lectularius, and H. halys. Genes manually annotated in the $D$. citri v3.0 genome are listed in the column labeled $D c$. Phylogenetic analysis was performed using sequences in Tables 2 and 3 (Figure 1). yellow- $f$ was not found in the genome or de novo transcriptome of $D$. citri, or in the hemipteran 
a)

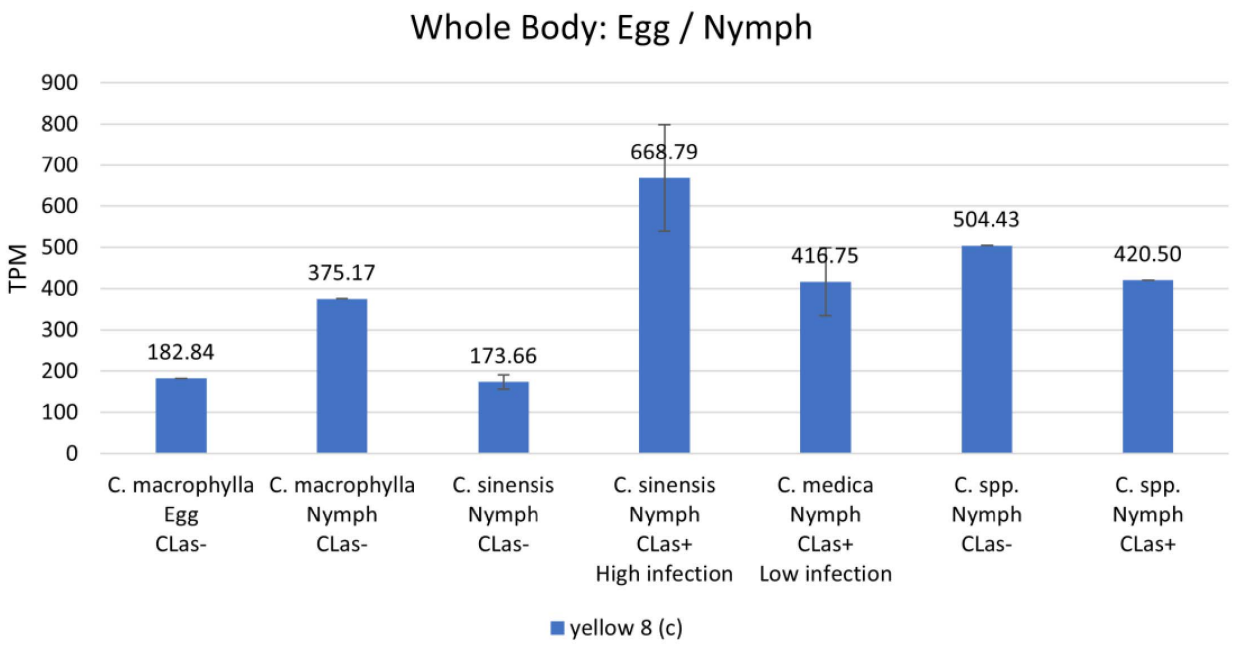

b)

\section{Gut / Midgut: Adult}

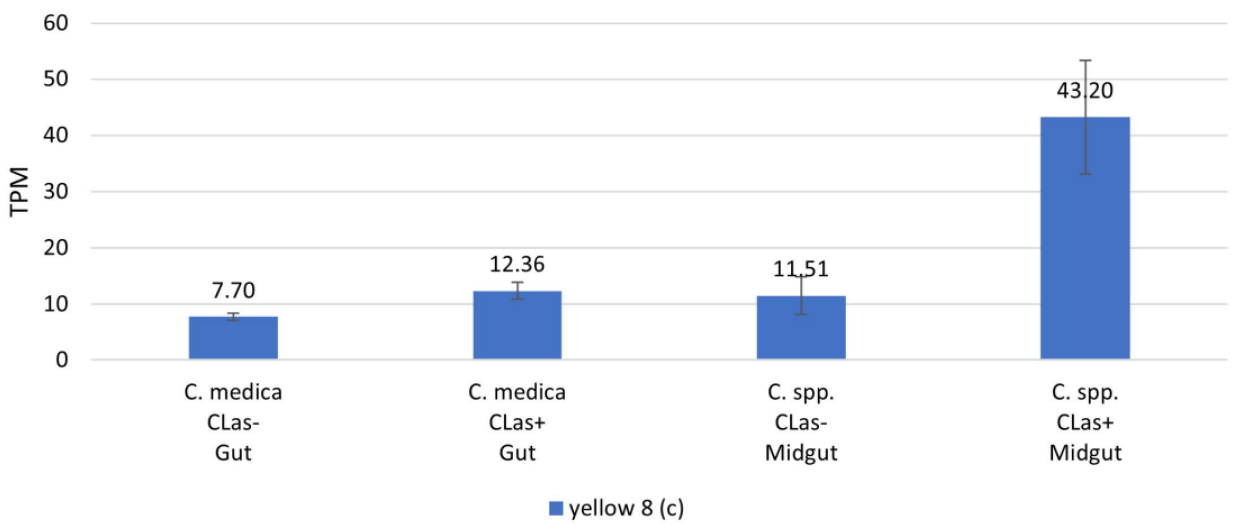

Figure 4. Comparative expression levels of the $D$. citri yellow $8(c)$ proteins in uninfected $D$. citri insects grown on various citrus varieties. Values are represented in transcripts per million (TPM). Expression data obtained using the Citrus Greening Expression Network [14]. (a) Comparative expression levels in the whole body of $D$. citri egg and nymphs. Eggs and nymphs raised on Citrus macrophylla [8] and nymphs raised on Citrus spp. [25] are single replicate data. RNA-seq data were sourced from insects raised on $C$. sinensis and $C$. medica (NCBI BioProject PRJNA609978). (b) Comparative expression levels in the gut [24] and midgut [26] of D. citri adults.

sequences used in this analysis. Instead, hemipterans formed a separate clade, which is labeled as yellow 9 here (Table 5, Figure 1).

\section{yellow-y}

The gene yellow-y (also simply referred to as yellow) was the first example of a single gene mutation affecting behavior [13]. However, yellow, was initially identified because of its role in pigmentation, and was named for the loss of black pigment that gave mutant flies a more yellow appearance [42]. Recent studies suggest that the Drosophila melanogaster yellow-y and ebony gene together determine the pattern and intensity of melanization [43], and that the yellow-y gene may regulate the expression of yellow- $f$ or other enzymes involved in melanization [10]. Many studies have also noted a role for yellow-y in the behavior and mating ability of Drosophila, such as changes in the structures used during 
Whole Body: Egg / Nymph

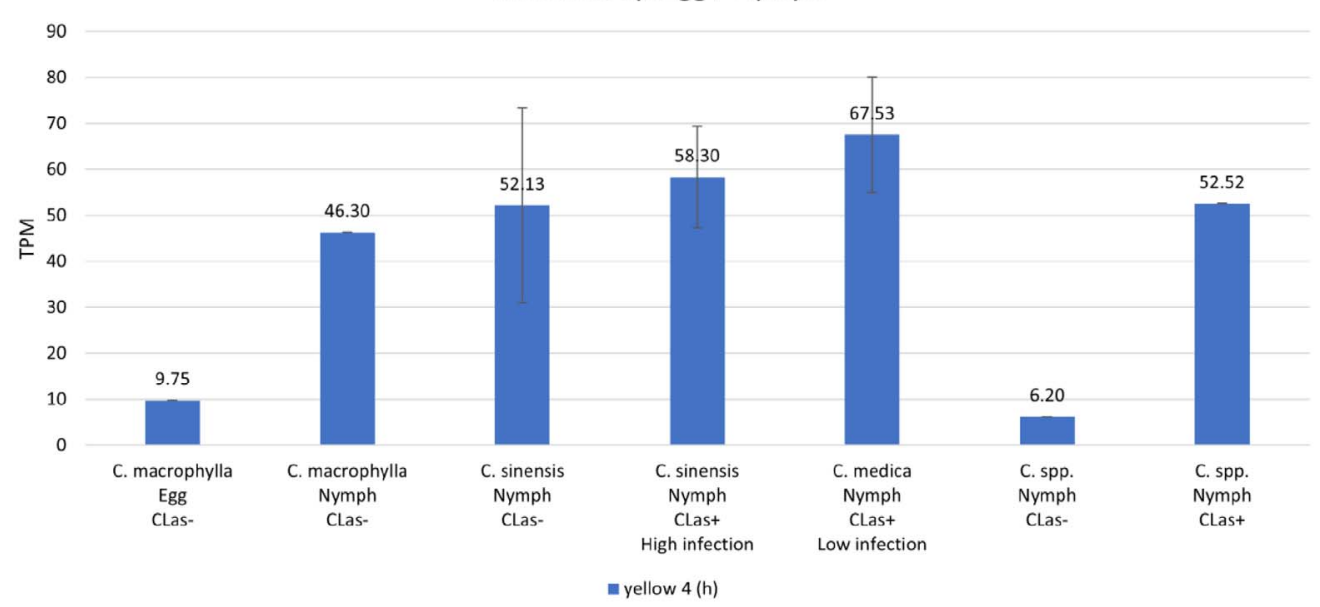

Figure 5. Comparative expression levels of the $D$. citri yellow 4 (h) proteins in eggs, nymphs and whole body infected and uninfected $D$. citri adults grown on various citrus varieties. Values are represented in transcripts per million (TPM). Eggs and nymphs raised on Citrus macrophylla [8] and nymphs raised on Citrus spp. [25] are single replicate data. RNA-seq data were sourced from insects raised on $C$. sinensis and $C$. medica (NCBI BioProject PRJNA609978). Expression analysis was performed using the Citrus Greening Expression Network [14].

Female vs. Male: Adult

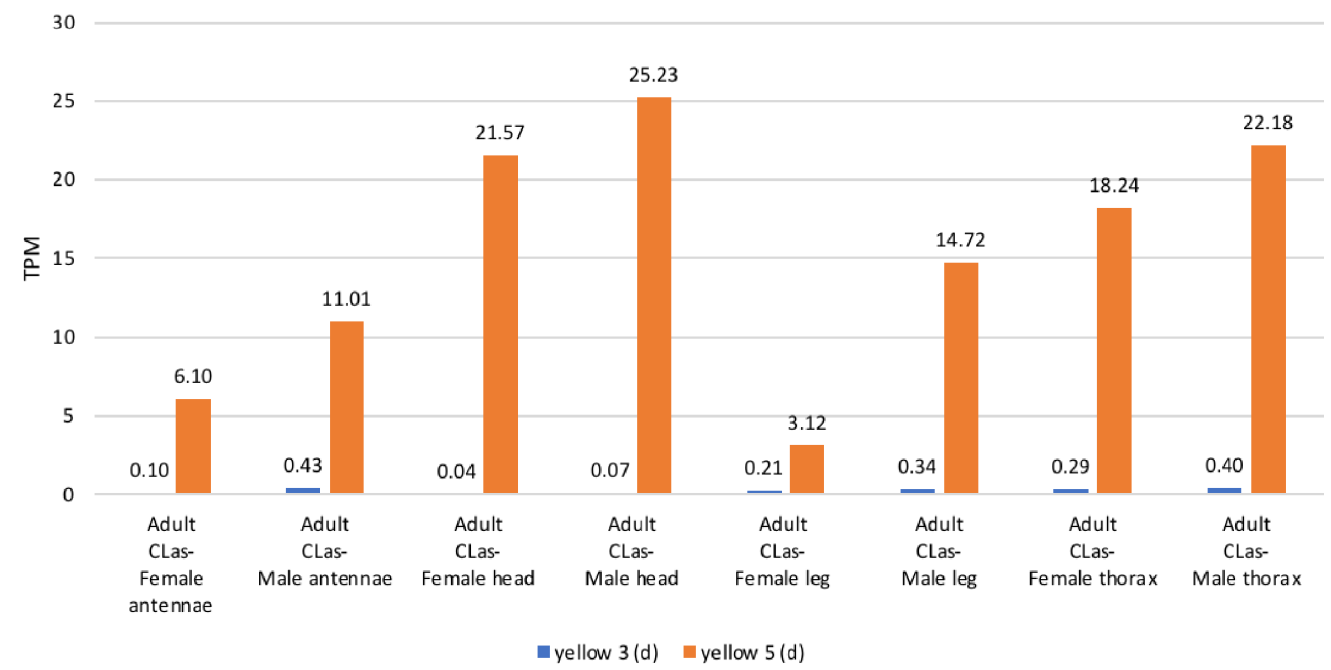

Figure 6. Comparative expression levels of the $D$. citri yellow-d proteins in female and male $D$. citri insects grown on C. reticulata. Expression data were obtained using the Citrus Greening Expression Network [14]. These samples from psyllid tissues have a single replicate and are from NCBI BioProject PRJNA448935.

mating in yellow mutants [13]. The yellow-y gene is present in most insect species as a single copy; however, both yellow and yellow 2 in $D$. citri form a clade exclusively with known yellow-y orthologs, indicating a duplication event that seems to be unique to $D$. citri (Figure 1). These two yellow-y genes show inverse expression patterns in D. citri; that is, yellow $(y)$ shows highest expression in the nymph, while yellow 2 (y2) shows highest expression in the adult (Figure 3). The high expression of yellow (y) in nymphs correlates 


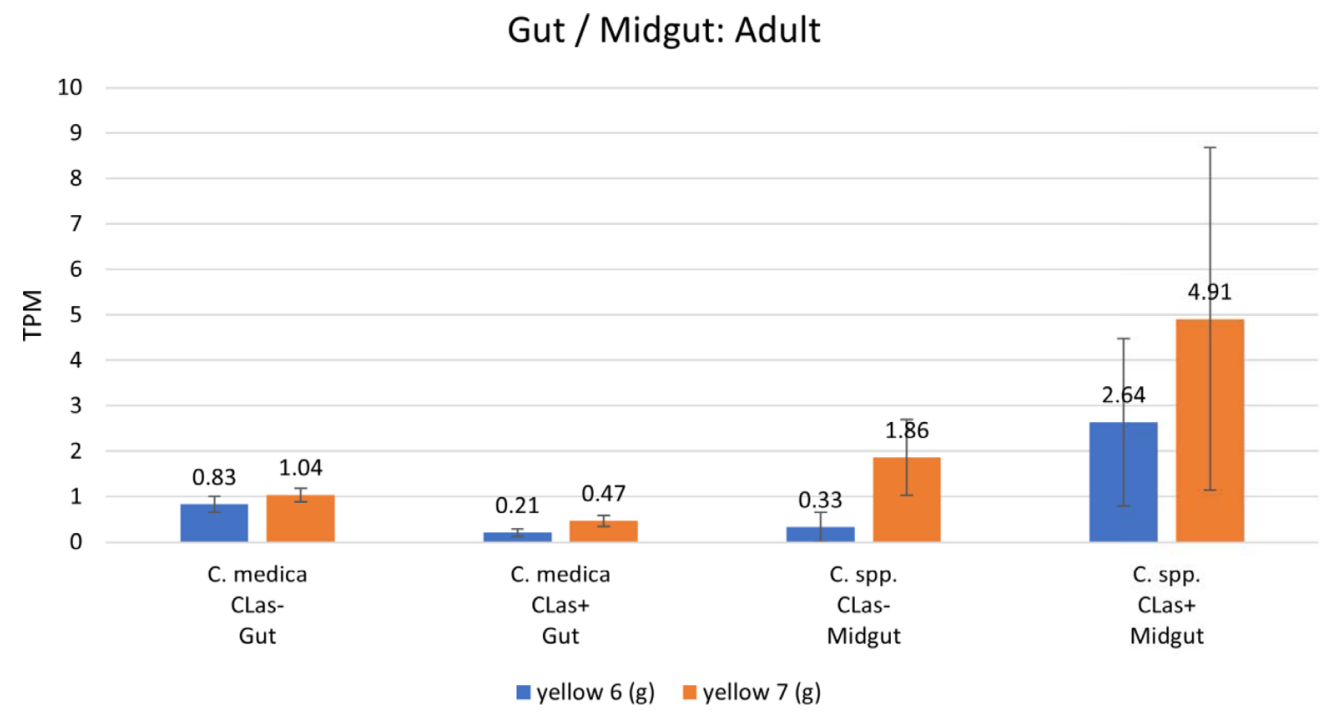

Figure 7. Comparative expression levels of the $D$. citri yellow 6 and yellow 7 (g) proteins in $D$. citri gut [24] and midgut [26] of infected and uninfected adult insects. Values are represented in transcripts per million (TPM). Expression data were obtained using the Citrus Greening Expression Network [14].

with research that found yellow-y to be abundant in Drosophila pupae when melanin is deposited in the adult cuticle [44]. On the other hand, yellow 2 (y2) may be important in adult $D$. citri and should be studied further.

\section{yellow-c, $-f,-b$, and 9}

No function has been directly identified for the yellow genes yellow-b or yellow-c. However, phylogenetic analysis reveals a close relationship between yellow-b, yellow-c, yellow-f, and yellow $9[11,27]$ (Figure 1). In Drosophila, yellow- $f$ and yellow- $f 2$ function as dopachrome conversion enzymes (DCE), which are important in melanin biosynthesis [43]. Interestingly, while most hemipterans seem to have one or more yellow-c genes, none form clades exclusively with known yellow- $f$ or yellow-b orthologs (Figure 1). Instead, hemipteran genes are grouped into their own separate clade. A close relationship was observed, however, between yellow- $f$ and yellow 9, which is supported by the presence of an Acyrthosiphon pisum sequence in the yellow 9 clade, previously reported as grouping with yellow- $f$ (Figure 1) [11]. The addition of several other hemipteran sequences may have helped align A. pisum more closely to the yellow 9 orthologs. This distinctness of the hemipteran group is common among the other yellow genes in the tree; however, the association to a known ortholog is typically much clearer than is seen with yellow 9. More studies should be conducted to conclusively determine the identity of this hemipteran outlier.

Of all yellow genes in D. citri, yellow 8 (c) shows the greatest expression levels and is most highly expressed in the adult whole body of $D$. citri insects reared on Citrus medica (Figure 3). There was a significant increase in expression in nymphs reared on CLas-positive Citrus sinensis, with 3.85-fold upregulation in whole nymphs (Figure 4a). The gene was also upregulated by 3.75-fold in the midgut of infected adult psyllids reared on Citrus spp. (Figure 4b). These results suggest an interaction between yellow 8 (c) and pathogen infection, therefore warranting further investigations. 


\begin{tabular}{|c|c|c|c|c|c|}
\hline Gene & $\begin{array}{c}\text { Drosophila } \\
\text { melanogaster }\end{array}$ & $\begin{array}{l}\text { Tribolium } \\
\text { castaneum }\end{array}$ & Bombyx mori & Apis mellifera & $\begin{array}{l}\text { Nasonia } \\
\text { vitripennis }\end{array}$ \\
\hline yellow-y & NP_476792.1 & NP_001161919.1 & NP_001037434.1 & NP_001091693.1 & NP_001154977.1 \\
\hline yellow-b & NP_523586.1 & NP_001161777.1 & & & NP_001154989.1 \\
\hline yellow-c & NP_523570.3 & NP_001161778.1 & NP_001037426.1 & & \\
\hline yellow- $f(f a)^{\dagger}$ & NP_524335.1 & NP_001161780.1 & NP_001037424.1 & NP_001011635.1 & NP_001154968.1 \\
\hline yellow- $f 2(f b)^{\dagger}$ & NP_650247.1 & & NP_001037428.1 & & \\
\hline yellow-h & NP_651912.3 & XP_008196499.1 & & NP_001091687.1 & NP_001153394.1 \\
\hline yellow-e & NP_524344.1 & NP_001161779.1 & NP_001159615.1 & XP_003249426.1 & NP_001154985.1 \\
\hline yellow-e2 & NP_650289.2 & & & & \\
\hline yellow-e3 & NP_650288.1 & NP_001161913.1 & & NP_001091698.1 & NP_001154982.1 \\
\hline yellow-d & NP_523820.2 & & NP_001037422.1 & & \\
\hline yellow-d2 & NP_611788.1 & & & & \\
\hline yellow-g & NP_523888.1 & ACY71060.1 & & XP_396824.1 & XP_008210364.1 \\
\hline yellow-g2 & NP_647710.1 & NP_001161782.1 & & XP_006559006.1 & \\
\hline yellow-k & NP_648772.1 & & & & \\
\hline yellow-1 $(x)^{\ddagger}$ & & NP_001161783.1 & & & \\
\hline yellow-2 $(x)^{\ddagger}$ & & NP_001161784.1 & & & \\
\hline yellow $-3(x)^{\ddagger}$ & & NP_001161785.1 & & & \\
\hline yellow-4 $(x)^{\ddagger}$ & & NP_001161786.1 & & & \\
\hline yellow $-5(x)^{\ddagger}$ & & NP_001165862.1 & & & \\
\hline yellow- $b(x)^{\ddagger}$ & & & NP_001037430.1 & & \\
\hline mrjp/yellow-e3 & & & & XP_001122824.1 & \\
\hline mrjp 1 & & & & NP_001011579.1 & \\
\hline mrjp 2 & & & & NP_001011580.1 & \\
\hline mrjp 3 & & & & NP_001011601.1 & \\
\hline mrjp 4 & & & & NP_001011610.1 & \\
\hline mrjp 5 & & & & NP_001011599.1 & \\
\hline mrjp 6 & & & & NP_001011622.1 & \\
\hline mrjp 7 & & & & NP_001014429.1 & \\
\hline mrjp 8 & & & & NP_001011564.1 & \\
\hline mrjp 9 & & & & NP_001019868.1 & \\
\hline
\end{tabular}

\section{yellow-h}

Transcripts of yellow-h show color-related expression patterns in some species, but the function of the encoded protein is poorly understood [11]. Phylogenetic analysis reveals that $D$. citri contains one yellow-h gene, yellow 4 (Table 5, Figure 1). Expression data from $D$. citri shows the highest expression of this gene in the egg and nymph (Figure 3). This is consistent with previous research showing that mutations of yellow- $h$ in larval Vanessa cardui led to death in pupal stages of development, suggesting that yellow-h could be important during insect development [27]. Furthermore, expression data revealed an 8.47-fold increase in yellow- $h$ expression in D. citri nymphs reared on Citrus spp. and infected with CLas (52.52 TPM) versus uninfected nymphs (6.2 TPM) (Figure 5). This differential expression of yellow- $h$, coupled with the impact of mutations in pupal mortality, indicates that yellow- $h$ could be a potential RNA interference (RNAi) target and warrants additional study in $D$. citri.

\section{yellow-e3/d}

Previous research has revealed that yellow- $d$ shows red-specific expression in the butterfly $V$. cardui, and that the loss of yellow- $d$ function not only affects melanin patterns, but also 


\begin{tabular}{|c|c|c|c|c|c|c|c|}
\hline Gene & $\begin{array}{c}\text { Acyrthosiphon } \\
\text { pisum }\end{array}$ & $\begin{array}{c}\text { Nilaparvata } \\
\text { lugens }\end{array}$ & Sipha Flava & Bemisia tabaci & $\begin{array}{l}\text { Halymorpha } \\
\text { halys }\end{array}$ & $\begin{array}{c}\text { Cimex } \\
\text { lectularius }\end{array}$ & $\begin{array}{c}\text { Oncopeltus } \\
\text { fasciatus }\end{array}$ \\
\hline yellow-y & NP_001165848.1 & XP_022184245.1 & XP_025405013.1 & & XP_014294277.1 & & AMW91813.1 \\
\hline \multirow[t]{2}{*}{ yellow-c } & XP_008189794.1 & XP_022204541.1 & XP_025415761.1 & XP_018916210.1 & XP_014273608.1 & XP_014260013.1 & \\
\hline & & & & XP_018902711.1 & & & \\
\hline \multirow[t]{2}{*}{ yellow-c2 } & XP_008189795 & & XP_025415762.1 & & & & \\
\hline & & & XP_025421542.1 & & & & \\
\hline yellow-h & XP_016656930.1 & XP_022203506.1 & & & XP_014273783.1 & XP_014247137.1 & \\
\hline \multirow[t]{3}{*}{ yellow-e } & XP_001948479.1 & XP_022204722.1 & & XP_018907407.1 & XP_014292044.1 & XP_024083966.1 & \\
\hline & & & & XP_018906454.1 & & XP_014239663.1 & \\
\hline & & & & XP_018907408.1 & & XP_014247778.1 & \\
\hline \multirow[t]{2}{*}{ yellow-d/e3 } & XP_001942700.2 & XP_022204983.1 & & XP_018916419.1 & XP_014275903.1 & XP_024083964.1 & \\
\hline & & XP_022205442.1 & & & & XP_024083953.1 & \\
\hline \multirow[t]{2}{*}{ yellow-g } & XP_001944949.2 & XP_022207733.1 & & & XP_014292984.1 & & \\
\hline & & XP_022191720.1 & & & & & \\
\hline yellow-g2 & XP_001945004.2 & XP_022205647.1 & & & XP_014292982.2 & XP_014244848.1 & \\
\hline yellow-x & & XP_022206946.1 & & XP_018912253.1 & & & \\
\hline \multirow[t]{2}{*}{ yellow 9} & XP_001946728.1 & & XP_025413197.1 & XP_018905078.1 & XP_014288983.1 & XP_014255102.1 & \\
\hline & & & & XP 018901286.1 & & & \\
\hline
\end{tabular}

presumptive ommochrome patterns [27]. Phylogenetic analysis of the yellow genes annotated in the $D$. citri genome shows yellow 3 and yellow 5 in a clade with known yellow-e3/d orthologs (Figure 1). Expression of yellow $3(d)$ was highest in the whole body of adult psyllids reared on Citrus medica, while those reared on C. macrophylla or C. spp. showed low expression. Similarly, expression was highest in nymphs raised on $C$. sinensis and $C$. medica, with almost no expression in psyllids reared on other citrus species (Figure 3). In insects reared on $C$. reticulata, expression of yellow $3(d)$ was consistently close to zero TPM, while yellow $5(d)$, showed relatively high expression in the adult antennae, head, and thorax (Figure 6).

\section{yellow-g}

The function of yellow-g is currently not well understood; however, it is often present in duplicate in most insects (Figure 1, Table 5). D. citri contains two yellow-g genes, yellow 6 and yellow 7, both of which are expressed more in adult males versus females raised on $C$. reticulata (Figure 3). The expression of both genes is relatively similar throughout the stages and tissues that have been assayed. Neither gene is expressed in the egg, and both show low expression levels in the nymph, with higher expression in adults. There is a notable upregulation of yellow $6(\mathrm{~g})$, from undetectable in uninfected nymphs raised on $C$. spp. to $4.01 \mathrm{TPM}$ in infected nymphs. There is also an upregulation of yellow $6(\mathrm{~g})$ by 8 -fold and yellow $7(g)$ by 2.64 -fold in the midgut of infected versus uninfected adult psyllids reared on $C$. spp. (Figure 7). This effect may indicate an immune response and should be studied further as a possible RNAi target.

\section{Conclusion}

The yellow gene family is a continuously evolving set of genes, with duplications and losses among insects [11]. Many of these genes are crucial in melanization, which is essential for insect survival in relation to development and immunity [10,12]. Though the function of some yellow proteins remain poorly understood, identification of these proteins in the 


\begin{tabular}{|c|c|c|c|c|c|c|c|c|c|}
\hline Gene Name & yellow (y) & yellow $2(y 2)$ & yellow $3(d)$ & yellow 4 (h) & yellow $5(d)$ & yellow $6(\mathrm{~g})$ & yellow 7 (g) & yellow $8(c)$ & yellow 9 \\
\hline Gene ID & $\begin{array}{l}\text { Dcitr06g10 } \\
150.1 .1\end{array}$ & $\begin{array}{c}\text { Dcitr03g068 } \\
60.1 .1\end{array}$ & $\begin{array}{c}\text { Dcitr07g07 } \\
\text { 190.1.1 }\end{array}$ & $\begin{array}{c}\text { Dcitr07g07 } \\
\text { 210.1.1 }\end{array}$ & $\begin{array}{c}\text { Dcitr11g08 } \\
710.1 .1\end{array}$ & $\begin{array}{c}\text { Dcitr02g17 } \\
880.1 .1\end{array}$ & $\begin{array}{c}\text { Dcitr11g06 } \\
750.1 .1\end{array}$ & $\begin{array}{l}\text { Dcitr01g01 } \\
210.1 .1\end{array}$ & $\begin{array}{c}\text { Dcitr01g05 } \\
760.1 .1\end{array}$ \\
\hline $\begin{array}{l}\text { Egg C.mac CLas- } \\
\text { Whole body }\end{array}$ & 11.99 & 11.1 & 0.27 & 9.75 & 4.14 & 0 & 0 & 182.84 & 1.94 \\
\hline $\begin{array}{l}\text { Nymph C.med CLas+ } \\
\text { Low inf Whole body }\end{array}$ & 277.12 & 5.89 & 23.24 & 67.53 & 5.72 & 2.98 & 3.72 & 416.75 & 0.49 \\
\hline $\begin{array}{l}\text { Nymph C.sin CLas+ } \\
\text { High inf Whole body }\end{array}$ & 263.14 & 3.42 & 15.73 & 58.3 & 5.63 & 4.32 & 4.86 & 668.79 & 0.31 \\
\hline $\begin{array}{l}\text { Nymph C.sin CLas- } \\
\text { Whole body }\end{array}$ & 153.79 & 4.14 & 18.8 & 52.13 & 4.97 & 2.63 & 2.95 & 173.66 & 0.53 \\
\hline $\begin{array}{l}\text { Nymph C.mac CLas- } \\
\text { Whole body }\end{array}$ & 193.67 & 2.57 & 0.14 & 46.3 & 17.03 & 1.88 & 1.92 & 375.17 & 1.57 \\
\hline $\begin{array}{l}\text { Nymph Citrus CLas- } \\
\text { Whole body }\end{array}$ & 32.81 & 0 & 0 & 6.2 & 9.78 & 0 & 0.29 & 504.43 & 0 \\
\hline $\begin{array}{l}\text { Nymph Citrus CLas }+ \\
\text { Whole body }\end{array}$ & 77.7 & 0 & 0 & 52.52 & 6.57 & 4.01 & 0.67 & 420.5 & 0.24 \\
\hline $\begin{array}{l}\text { Adult C.med CLas- } \\
\text { Gut }\end{array}$ & 0.06 & 0.76 & 0.15 & 0.88 & 0.21 & 0.83 & 1.04 & 7.7 & 0.08 \\
\hline Adult C.med CLas+ Gut & 0.05 & 0.67 & 0.11 & 1.25 & 0.3 & 0.21 & 0.47 & 12.36 & 0 \\
\hline $\begin{array}{l}\text { Adult C.med CLas+ } \\
\text { High inf Whole body }\end{array}$ & 10.89 & 17.9 & 96.66 & 0.73 & 8.8 & 13.47 & 17.05 & 1225.4 & 1.28 \\
\hline $\begin{array}{l}\text { Adult C.med CLas }+ \\
\text { Low inf Whole body }\end{array}$ & 10.24 & 15.63 & 53.75 & 1.55 & 8.25 & 14.6 & 23.59 & 838.49 & 1.43 \\
\hline $\begin{array}{l}\text { Adult C.med CLas- } \\
\text { Whole body }\end{array}$ & 26.67 & 10.11 & 59.97 & 1.44 & 10.19 & 11.3 & 13.59 & 1477.39 & 1.51 \\
\hline $\begin{array}{l}\text { Adult C.mac CLas- } \\
\text { Whole body }\end{array}$ & 2.93 & 18.26 & 3.03 & 0.08 & 13.73 & 31.72 & 42.71 & 526.9 & 1.9 \\
\hline $\begin{array}{l}\text { Adult Citrus CLas- } \\
\text { Whole body }\end{array}$ & 2.57 & 19.78 & 1.93 & 1.54 & 15.41 & 30.8 & 30.71 & 440.97 & 1.4 \\
\hline $\begin{array}{l}\text { Adult Citrus } C \text { Las }+ \\
\text { Whole body }\end{array}$ & 2 & 24.29 & 2.71 & 0.45 & 16.75 & 14.24 & 19.45 & 313.19 & 2.24 \\
\hline $\begin{array}{c}\text { Adult Citrus CLas- } \\
\text { Midgut }\end{array}$ & 0.12 & 2.32 & 0.08 & 0.28 & 1.84 & 0.33 & 1.86 & 11.51 & 1.34 \\
\hline $\begin{array}{c}\text { Adult Citrus } C \text { Las }+ \\
\text { Midgut }\end{array}$ & 0.2 & 2.89 & 0.01 & 0.6 & 1.14 & 2.64 & 4.91 & 43.2 & 0.83 \\
\hline $\begin{array}{l}\text { Adult C.ret CLas- } \\
\text { Female abdomen }\end{array}$ & 2.3 & 13.87 & 0.3 & 0.27 & 1.54 & 0 & 0.81 & 36.91 & 4.62 \\
\hline $\begin{array}{l}\text { Adult C.ret CLas- } \\
\text { Female antennae }\end{array}$ & 3.43 & 5.73 & 0.1 & 0.59 & 6.1 & 0.07 & 1 & 394.88 & 4.45 \\
\hline $\begin{array}{l}\text { Adult C.ret CLas- } \\
\text { Female head }\end{array}$ & 0.22 & 4.88 & 0.04 & 0.1 & 21.57 & 0 & 0 & 551.85 & 6.29 \\
\hline $\begin{array}{l}\text { Adult C.ret CLas- } \\
\text { Female leg }\end{array}$ & 1.4 & 3.64 & 0.21 & 0.05 & 3.12 & 0 & 0.31 & 526.89 & 4.09 \\
\hline $\begin{array}{l}\text { Adult C.ret CLas- } \\
\text { Female terminal } \\
\text { abdomen }\end{array}$ & 6.01 & 7.65 & 0.22 & 0.11 & 0.2 & 0.44 & 0 & 736.67 & 0.9 \\
\hline $\begin{array}{l}\text { Adult C.ret CLas- } \\
\text { Female thorax }\end{array}$ & 0.22 & 5.45 & 0.29 & 0.13 & 18.24 & 0 & 0 & 497.24 & 7.32 \\
\hline $\begin{array}{l}\text { Adult C.ret CLas- } \\
\text { Male abdomen }\end{array}$ & 2.04 & 15.45 & 0.14 & 0.12 & 1.13 & 11.08 & 35.83 & 46.05 & 6.7 \\
\hline $\begin{array}{l}\text { Adult C.ret CLas- } \\
\text { Male antennae }\end{array}$ & 5.47 & 5.72 & 0.43 & 0.31 & 11.01 & 2.12 & 12.49 & 301.88 & 5.14 \\
\hline $\begin{array}{l}\text { Adult C.ret CLas- } \\
\text { Male head }\end{array}$ & 0.24 & 3.36 & 0.07 & 0.4 & 25.23 & 0 & 0.34 & 475.06 & 9.67 \\
\hline $\begin{array}{l}\text { Adult C.ret CLas- } \\
\text { Male leg }\end{array}$ & 2.25 & 4.08 & 0.34 & 0.1 & 14.72 & 2.86 & 8.42 & 462.7 & 5.79 \\
\hline $\begin{array}{l}\text { Adult C.ret CLas- Male } \\
\text { terminal abdomen }\end{array}$ & 2.74 & 5.64 & 0.24 & 0.22 & 1.33 & 6.55 & 15.52 & 512.54 & 2.41 \\
\hline $\begin{array}{l}\text { Adult C.ret CLas- } \\
\text { Male thorax }\end{array}$ & 1.35 & 4.26 & 0.4 & 0.19 & 22.18 & 0.83 & 2.21 & 442.87 & 3.44 \\
\hline $\begin{array}{l}\text { Adult C.ret CLas- } \\
\text { Female antennae [23] }\end{array}$ & 1.24 & 8.43 & 0.1 & 0.06 & 34.97 & 0 & 0.78 & 347.77 & 4.59 \\
\hline
\end{tabular}




\begin{tabular}{|c|c|c|c|c|c|c|c|c|c|}
\hline Gene Name & yellow (y) & yellow $2(y 2)$ & yellow $3(d)$ & yellow $4(h)$ & yellow $5(d)$ & yellow $6(\mathrm{~g})$ & yellow 7 (g) & yellow 8 (c) & yellow 9 \\
\hline Gene ID & $\begin{array}{l}\text { Dcitr06g10 } \\
150.1 .1\end{array}$ & $\begin{array}{c}\text { Dcitr03g068 } \\
60.1 .1\end{array}$ & $\begin{array}{c}\text { Dcitr07g07 } \\
\text { 190.1.1 }\end{array}$ & $\begin{array}{c}\text { Dcitr07g07 } \\
\text { 210.1.1 }\end{array}$ & $\begin{array}{c}\text { Dcitr11g08 } \\
710.1 .1\end{array}$ & $\begin{array}{c}\text { Dcitr02g17 } \\
\text { 880.1.1 }\end{array}$ & $\begin{array}{c}\text { Dcitr11g06 } \\
\text { 750.1.1 }\end{array}$ & $\begin{array}{c}\text { Dcitr01g01 } \\
210.1 .1\end{array}$ & $\begin{array}{c}\text { Dcitr01g05 } \\
760.1 .1\end{array}$ \\
\hline $\begin{array}{l}\text { Adult C.ret CLas- } \\
\text { Female terminal } \\
\text { abdomen [23] }\end{array}$ & 1.74 & 12.71 & 0.31 & 0.11 & 2.39 & 0 & 0.49 & 80.69 & 1.45 \\
\hline $\begin{array}{l}\text { Adult C.ret CLas- } \\
\text { Male antennae [23] }\end{array}$ & 1.06 & 6.25 & 0.15 & 0.32 & 37.56 & 1.29 & 2.79 & 279.33 & 9.62 \\
\hline $\begin{array}{l}\text { Adult C.ret CLas- } \\
\text { Male terminal } \\
\text { abdomen [23] }\end{array}$ & 1.86 & 20.22 & 0.31 & 0.04 & 1.73 & 16.89 & 33.47 & 189.24 & 5.62 \\
\hline \multicolumn{10}{|c|}{$\begin{array}{l}\text { Comparative expression levels in transcripts per million (TPM) of the D. citri yellow-y proteins in infected versus uninfected } D \text {. citri insects grown on various } \\
\text { citrus varieties. Expression data were obtained using the Citrus Greening Expression Network [14]. RNA-Seq data for psyllids were obtained from NCBI } \\
\text { BioProject’s PRJNA609978 and PRJNA448935, in addition to published datasets [8,23-26]. Citrus hosts are abbreviated as C.sin (C. sinensis), C.med (C. medica), } \\
\text { C.ret (C. reticulata) and C.mac (C. macrophylla). }\end{array}$} \\
\hline
\end{tabular}

\begin{tabular}{|c|c|c|c|c|c|c|c|c|c|c|c|}
\hline Gene & $D c$ & $A p$ & $A m$ & $T c$ & $D m$ & $B m$ & $S f$ & $B t$ & $N l$ & $\mathrm{Cl}$ & Hh \\
\hline yellow-y & 2 & 1 & 1 & 1 & 1 & 1 & 1 & 0 & 1 & 0 & 1 \\
\hline yellow-b & 0 & 0 & 0 & 1 & 1 & 0 & 0 & 0 & 0 & 0 & 0 \\
\hline yellow- $f$ & 0 & 0 & 1 & 1 & 2 & 2 & 0 & 0 & 0 & 0 & 0 \\
\hline yellow 9 & 1 & 1 & 0 & 0 & 0 & 0 & 1 & 2 & 0 & 1 & 1 \\
\hline yellow-c & 1 & 2 & 0 & 1 & 1 & 1 & 3 & 2 & 1 & 1 & 1 \\
\hline yellow-h & 1 & 1 & 1 & 1 & 1 & 0 & 0 & 0 & 1 & 1 & 1 \\
\hline yellow-d/e3 & 2 & 1 & 1 & 1 & 4 & 1 & 0 & 1 & 2 & 2 & 1 \\
\hline yellow-e & 0 & 1 & 1 & 1 & 1 & 1 & 0 & 3 & 1 & 3 & 1 \\
\hline yellow-g & 2 & 2 & 2 & 2 & 2 & 0 & 0 & 0 & 2 & 1 & 2 \\
\hline yellow-x & 0 & 0 & 0 & 5 & 0 & 1 & 0 & 1 & 1 & 0 & 0 \\
\hline yellow-k & 0 & 0 & 0 & 0 & 1 & 0 & 0 & 0 & 0 & 0 & 0 \\
\hline$m r j p^{\dagger}$ & 0 & 0 & 10 & 0 & 0 & 0 & 0 & 0 & 0 & 0 & 0 \\
\hline \multicolumn{12}{|c|}{$\begin{array}{l}\text { The yellow gene family ortholog numbers based on results of the phylogenetic analysis (Figure } 1 \text { ). } D c \text { numbers } \\
\text { represent the number of manually annotated genes in the } D \text {. citri v3.0 genome. }{ }^{\dagger} \text { Copy number in } A m \text { includes a } \\
\text { predicted sequence from NCBI that groups with mrjp in phylogenetic analysis. }\end{array}$} \\
\hline
\end{tabular}

hemipteran, $D$. citri, provides a novel insect lineage for studies of insect evolution and biology. $D$. citri harbors a unique duplication of yellow-y, a gene that may affect cuticular hardening. Therefore, it could be a potential target for a $D$. citri-specific molecular control mechanism [13]. Expression data shows an inverse relationship between the two yellow-y genes, suggesting independent roles for these proteins during juvenile and adult stages (Figure 3). The yellow 9 gene appears to be unique to hemipterans (Figure 1), and is a potential alternative to yellow- $f$ in holometabolous insects, which encodes a dopachrome conversion enzyme (DCE) in Drosophila [43].

\section{REUSE POTENTIAL}

The manually curated gene models based on the highly contiguous version 3 genome, compared with previous assemblies, provide a novel resource for understanding psyllid biology for the citrus greening community. To improve the accessibility and usability of this data, it will be included in the Psyllid Expression Network [14]. This visualization and analysis tool includes public transcriptomics data for Diaphorina citri from multiple tissues, life stages, infection states and citrus hosts in an expression cube for comparative analysis. Future directed studies are required to confirm the role of yellow-9. Continued examination 
of the yellow gene family across arthropods, and especially in insect vectors like $\mathrm{D}$. citri, provide novel and species-specific gene targets, potentially through the use of RNAi, to control psyllid populations and reduce the effects of pathogens, such as CLas, causing citrus greening.

\section{DATA AVAILABILITY}

The data sets supporting this article are available in the GigaScience GigaDB repository [45].

\section{EDITOR'S NOTE}

This article is one of a series of Data Releases crediting the outputs of a student-focused and community-driven manual annotation project, curating gene models and - if required correcting assembly anomalies, for the Diaphorina citri genome project [18].

\section{DECLARATIONS}

\section{LIST OF ABBREVIATIONS}

Am: Apis mellifera; Ap: Acyrthosiphon pisum; BLASTp: protein BLAST; Bm: Bombyx mori; Bt: Bemisia tabaci; Cl: Cimex lectularius; CLas: Candidatus Liberibacter asiaticus; DCE: dopachrome conversion enzyme; Dc: Diaphorina citri; Dm: Drosophila melanogaster; Hh: Halyomorpha halys; Iso-seq: Isoform sequencing; MCOT: Maker, Cufflinks, Oasis, Trinity; mrjp: major royal jelly protein; NCBI: National Center for Biotechnology Information; Nl: Nilaparvata lugens; CGEN: Citrus Greening Expression Network; RNAi: RNA interference; RNA-seq: RNA sequencing; $S f$ : Sipha flava; Tc: Tribolium castaneum; TPM: transcripts per million.

\section{ETHICAL APPROVAL}

Not applicable.

\section{CONSENT FOR PUBLICATION}

Not applicable.

\section{COMPETING INTERESTS}

The authors declare that they have no competing interests.

\section{AUTHORS' CONTRIBUTIONS}

WBH, SJB, TD and LAM conceptualized the study; TD, SS, TDS and SJB supervised the study; SJB, TD, SS and LAM contributed to project administration; CM and CV conducted investigation; PH, MF-G and SS contributed to software development; PH, MF-G, SS, TDS and JB developed methodology; SJB, TD, WBH and LAM acquired funding; CM prepared and wrote the original draft; TD, SJB, SS, TDS, WBH and JB reviewed and edited the draft.

\section{FUNDING}

This work was supported by USDA-NIFA grants 2015-70016-23028, HSI 1300394 and 2020-70029-33199.

\section{ACKNOWLEDGEMENTS}

We would like to thank Helen Wiersma-Koch (Indian River State College) and Thomson Paris (USDA-ARS-Horticultural Research Laboratories) for assistance. 


\section{REFERENCES}

1 Dala-Paula BM et al. Effect of Huanglongbing or greening disease on orange juice quality, a review. Front. Plant Sci., 2019; 9: 1976.

2 Hunter WB, Sinisterra-Hunter XH, Chapter Six. Emerging RNA suppression technologies to protect citrus trees from citrus greening disease bacteria. In: Smagghe G (ed.), Advances in Insect Physiology. London: Academic Press, 2018; pp. 163-197.

3 Hunter WB et al. Advances in RNA suppression of the Asian citrus psyllid vector and bacteria (huanglongbing pathosystem). In: Qureshi JA, Stansly PA (eds), Asian Citrus Psyllid: Biology, Ecology and Management of the Huanglongbing Vector. Wallingford: CABI, 2020; pp. 258-284.

4 National Academies of Science Engineering and Medicine (NASEM). A review of the citrus greening research and development efforts supported by the citrus research and development foundation: fighting a ravaging disease. In: Consensus Study Report. Washington, DC: National Academies Press, 2018.

5 Wang N, Stelinski LL, Pelz-Stelinski KS, Graham JH, Zhang Y, Tale of the Huanglongbing disease pyramid in the context of the citrus microbiome. Phytopathology, 2017; 107: 380-387.

6 Hall DG, Richardson ML, Ammar E-D, Halbert SE, Asian citrus psyllid, Diaphorina citri, vector of citrus huanglongbing disease. Entomol. Exp. Appl., 2013; 146: 207-223.

7 Arp AP, Hunter WB, Pelz-Stelinski KS, Annotation of the Asian citrus psyllid genome reveals a reduced innate immune system. Front. Physiol., 2016; 7: 570.

8 Reese J et al. Characterization of the Asian citrus psyllid transcriptome. J. Genomics, 2014; 2: 54-58.

9 Saha $\mathbf{S}$ et al. Improved annotation of the insect vector of citrus greening disease: biocuration by a diverse genomics community. Database (Oxford), 2017; bax032.

10 Noh MY, Kramer KJ, Muthukrishnan S, Beeman RW, Kanost MR, Arakane Y, Loss of function of the yellow-e gene causes dehydration-induced mortality of adult Tribolium castaneum. Dev. Biol., 2015; 399 : 315-324.

11 Ferguson LC, Green J, Surridge A, Jiggins CD, Evolution of the insect yellow gene family. Mol. Biol. Evol., 2011; 28: 257-272.

12 Nakhleh J, El Moussawi L, Osta MA, Chapter Three. The melanization response in insect immunity. In: Ligoxygakis P (ed.), Advances in Insect Physiology. London: Academic Press, 2017; pp. 83-109.

13 Massey JH, Chung D, Siwanowicz I, Stern DL, Wittkopp PJ, The yellow gene influences Drosophila male mating success through sex comb melanization. Elife, 2019; 8: e49388.

14 Flores-Gonzalez $M$ et al. Citrusgreening.org: An open access and integrated systems biology portal for the Huanglongbing (HLB) disease complex. BioRxiv. 2019; https://doi.org/10.1101/868364.

15 Drapeau MD, Albert S, Kucharski R, Prusko C, Maleszka R, Evolution of the Yellow/Major Royal Jelly Protein family and the emergence of social behavior in honey bees. Genome Res., 2006; 16: 1385-1394.

16 Hosmani PS et al. A quick guide for student-driven community genome annotation. PLoS Comput. Biol., 2019; 15: e1006682.

17 National Center for Biotechnology Information (NCBI) protein database. https://www.ncbi.nlm.nih.gov/protein. Accessed 2019.

18 Hosmani PS et al. Chromosomal length reference assembly for Diaphorina citri using single-molecule sequencing and $\mathrm{Hi}-\mathrm{C}$ proximity ligation with manually curated genes in developmental, structural and immune pathways. BioRxiv. Cold Spring Harbor Laboratory; 2019; https://doi.org/10.1101/869685.

19 Kumar S, Stecher G, Tamura K, MEGA7: Molecular Evolutionary Genetics Analysis version 7.0 for bigger datasets. Mol. Biol. Evol., 2016; 33: 1870-1874.

20 Shippy T et al. Annotating genes in Diaphorina citri genome version 3. protocols io. 2020; https://dx.doi.org/10.17504/protocols.io.bniimcce.

21 R Core Team. R: A language and environment for statistical computing. Vienna: R Foundation for Statistical Computing, 2020.

22 Kolde R, pheatmap: Pretty Heatmaps (Version 1.0.12). 2020; https://cran.r-project.org/package=pheatmap.

23 Wu Z, Zhang H, Bin S, Chen L, Han Q, Lin J, Antennal and abdominal transcriptomes reveal chemosensory genes in the Asian citrus psyllid, Diaphorina citri. PLoS One, 2016; 11: e0159372. 
24 Kruse A et al. Combining 'omics and microscopy to visualize interactions between the Asian citrus psyllid vector and the Huanglongbing pathogen Candidatus Liberibacter asiaticus in the insect gut. PLoS One, 2017; 12: e0179531.

25 Vyas M et al. Asian citrus psyllid expression profiles suggest Candidatus Liberibacter asiaticus-mediated alteration of adult nutrition and metabolism, and of nymphal development and immunity. PLoS One, 2015; 10: e0130328.

26 Yu H-Z et al. Transcriptome analyses of Diaphorina citri midgut responses to Candidatus Liberibacter asiaticus infection. Insects, 2020; 11: 171.

27 Zhang L et al. Genetic basis of melanin pigmentation in butterfly wings. Genetics, 2017; 205: $1537-1550$.

28 Thurmond J et al. FlyBase 2.0: the next generation. Nucleic Acids Res., 2019; 47: D759-D765.

29 Richards S et al. Tribolium Genome Sequencing Consortium. The genome of the model beetle and pest Tribolium castaneum. Nature, 2008; 452: 949-955.

30 Arakane $\mathbf{Y}$ et al. Identification, mRNA expression and functional analysis of several yellow family genes in Tribolium castaneum. Insect Biochem. Mol. Biol., 2010; 40: 259-266.

31 Kawamoto $\mathbf{M}$ et al. High-quality genome assembly of the silkworm, Bombyx mori. Insect Biochem. Mol. Biol., 2019; 107: 53-62.

32 Elsik CG et al. Finding the missing honey bee genes: lessons learned from a genome upgrade. BMC Genomics, 2014; 15: 86.

33 Werren JH et al. Functional and evolutionary insights from the genomes of three parasitoid Nasonia species. Science, 2010; 327: 343-348.

34 International Aphid Genomics Consortium. Genome sequence of the pea aphid Acyrthosiphon pisum. PLoS Biol., 2010; 8: e1000313.

35 Xue J et al. Genomes of the rice pest brown planthopper and its endosymbionts reveal complex complementary contributions for host adaptation. Genome Biol., 2014; 15: 521.

36 Ma W et al. Chromosomal-level genomes of three rice planthoppers provide new insights into sex chromosome evolution. Mol. Ecol. Resour., 2020; 21: 226-237.

37 O’Leary NA et al. Reference sequence (RefSeq) database at NCBI: current status, taxonomic expansion, and functional annotation. Nucleic Acids Res., 2016; 44: D733-D745.

38 Chen $\mathbf{W}$ et al. The draft genome of whitefly Bemisia tabaci MEAM1, a global crop pest, provides novel insights into virus transmission, host adaptation, and insecticide resistance. BMC Biol., 2016; 14: 110.

39 Sparks ME et al. Brown marmorated stink bug, Halyomorpha halys (Stål), genome: putative underpinnings of polyphagy, insecticide resistance potential and biology of a top worldwide pest. BMC Genomics, 2020; 21: 227.

40 Benoit JB et al. Unique features of a global human ectoparasite identified through sequencing of the bed bug genome. Nat. Commun., 2016; 7: 10165.

41 Panfilio KA et al. Molecular evolutionary trends and feeding ecology diversification in the Hemiptera, anchored by the milkweed bug genome. Genome Biol., 2019; 20: 64.

42 Morgan TH, The origin of nine wing mutations in Drosophila. Science, 1911; 33: 496-499.

43 Han Q, Fang J, Ding H, Johnson JK, Christensen BM, Li J, Identification of Drosophila melanogaster yellow-f and yellow-f2 proteins as dopachrome-conversion enzymes. Biochem. J., 2002; 368: 333-340.

44 Biessmann H, Molecular analysis of the yellow gene (y) region of Drosophila melanogaster. Proc. Natl Acad. Sci. USA, 1985; 82: 7369-7373.

45 Massimino C, Vosburg C, Shippy TD, Hosmani PS, Flores-Gonzalez M, Mueller LA, Hunter WB, Benoit JB, Brown SJ, D'Elia T, Saha S, Supporting data for “Annotation of yellow genes in Diaphorina citri, vector for the Huanglongbing disease”. GigaScience Database. 2021;

http://dx.doi.org/10.5524/100899. 